\title{
Germination, sanity, and store of Myracrodruon balansae diaspores
}

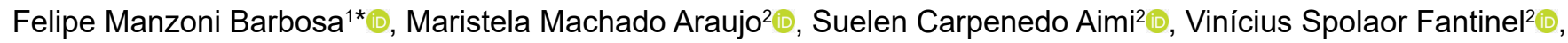 \\ Marlove Fátima Brião Muniz ${ }^{2}$, Adriana Maria Griebeler²®, Felipe Turchetto ${ }^{\circledR}$, Ezequiel Gasparin²

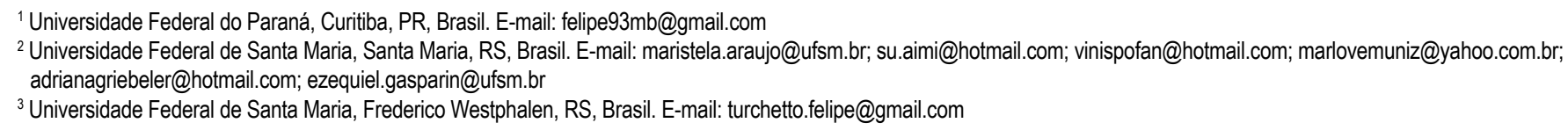

ABSTRACT: Many native woody species in Brazil still lack of seed technology studies. Myracrodruon balansae (Anacardiaceae) is a commercially endangered species with few studies. Thus, the objective of this study was to determine the influence of different substrates on germination and to evaluate the appropriate environment for storage and fungi associated with $M$. balansae diaspores. Two experiments were performed to choose the suitable substrate for germination tests: on top of sieved sand, between two layers of sieved sand, on top of vermiculite, between two layers of vermiculite, on top of blotter paper, between blotter paper, into paper rolls, and to evaluate their storage potential, and the associated fungi in three environmental conditions: wet cold chamber, refrigerator, and room temperature, for 18 months. Based on the results, germination tests can be performed on the substrates: on top of sieved sand, on top of vermiculite, between two layers of vermiculite, and on top of blotter paper. The diaspores could be stored with a water content of $10 \%$, in a refrigerator at $3{ }^{\circ} \mathrm{C}$, and $48 \%$ of relative humidity for 18 months, with only $18 \%$ of germination capacity loss. The main genera of fungi associated with stored seeds were Alternaria, Aspergillus, and Penicillium.

Key words: Anacardiaceae; seed technology; seed fungi; substrate; threatened species

\section{Germinação, sanidade e armazenamento de diásporos de Myracrodruon balansae}

RESUMO: Muitas espécies nativas do Brasil ainda carecem de estudos voltados à tecnologia de sementes. Myracrodruon balansae (Anacardiaceae) é uma espécie ameaçada de extinção com potencial comercial pouco estudada. Assim, o objetivo desse estudo foi determinar a influência de diferentes substratos na germinação e avaliar 0 ambiente adequado para 0 armazenamento e fungos associados aos diásporos de $M$. balansae. Para isso foram realizados dois experimentos para escolher o substrato adequado para testes de germinação: sobre areia, entre areia, sobre vermiculita, entre vermiculita, sobre papel filtro, entre papel filtro e em rolos de papel, e avaliar o potencial de armazenamento e a ocorrência de fungos de sementes em três ambientes, geladeira, câmara fria e laboratório durante 18 meses. Com base nos resultados, o teste de germinação pode ser realizado nos substratos: sobre areia, sobre vermiculita, entre vermiculita e sobre papel filtro. Os diásporos podem ser armazenados a $10 \%$ de umidade, na geladeira com $3^{\circ} \mathrm{C} \mathrm{e} 48 \%$ de umidade relativa do ar por 18 meses, com a perda de $18 \%$ da capacidade de germinação inicial. Os principais gêneros de fungos associados aos diásporos foram Alternaria, Aspergillus e Penicillium.

Palavras-chave: Anacardiaceae; tecnologia de sementes; fungos de sementes; substrato; espécie ameaçada

\footnotetext{
* Felipe Manzoni Barbosa - E-mail: felipe93mb@gmail.com (Corresponding author)

Associate Editor: Riselane de Lucena Alcântara Bruno
} 


\section{Introduction}

Seedling production and ex situ germplasm conservation, depends on high-quality seeds with optimal physical, physiological, phytosanitary, and genetic aspects, besides the capacity to tolerate desiccation, in order to allow longterm storing for different purposes (Contreras-Toledo et al., 2019). The knowledge of standardized methods to evaluate seed viability and factors influencing seed conservation is fundamental to standardize seed testing and seed storing (Hoffmann et al., 2015). Nonetheless, seeds of Brazilian native forest species are rarely studied regarding their germination and storage capacity when compared to agronomically relevant (Aimi et al., 2016). These studies are fundamental to support the high-quality production of seedlings and the annual supply of specimens for propagation (Hoffmann et al., 2015).

Myracrodruon balansae (Engl.) D. A. Santin (Anacardiaceae) is a semideciduous hard-wood species (density of $1.23 \mathrm{~g} \mathrm{~cm}^{-3}$ ), occurring in Argentina, Paraguay, and Southern Brazil. It can be used as a structural element in rural buildings and as the primary source of furniture wood in these regions, due to its wood quality, this species was widely logged over the last century (Carvalho, 2003), resulting in overexploitation and reduction of its natural populations. In the State of Rio Grande do Sul, its natural populations are currently restricted to less than $500 \mathrm{~km}^{2}$, in a small geographic area, leading to its categorization as an endangered species in Brazil (Luz et al.,
2013). Myracrodruon balansae is an early secondary woody species, with possible uses for the restoration of degraded areas, due to its fast growth and tolerance to droughts (Carvalho, 2003). Nevertheless, few studies related to seed technology for $M$. balansae are available in the literature. Furthermore, this species is not included in the Brazilian Rules for Seed Testing (Brasil, 2009a), nor the Brazilian Instructions for Seed Analyses of Forest Species (Brasil, 2013).

Due to the current vulnerability of this species in its natural environment, we hypothesize that finding suitable substrates for germination could contribute to a faster germination process and standardization of the proper physical, physiological, and sanitary qualities for storing diaspores of $M$. balansae. Two experiments were performed aiming to determine the influence of different substrates on germination, evaluate the time and suitable environmental conditions for diaspore storing, and the diaspore-borne fungi associated with storing.

\section{Materials and methods}

\section{Diaspores collection and processing}

Mature diaspores (fruits) were collected from 23 mother trees in March 2016, at least 50 m apart from each other, in remnants of deciduous forests in the municipality of

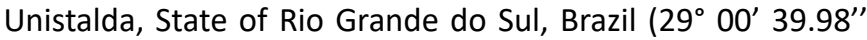
$S, 55^{\circ} 14^{\prime} 54.43^{\prime \prime}$ W) (Figure 1). Right after field collection,

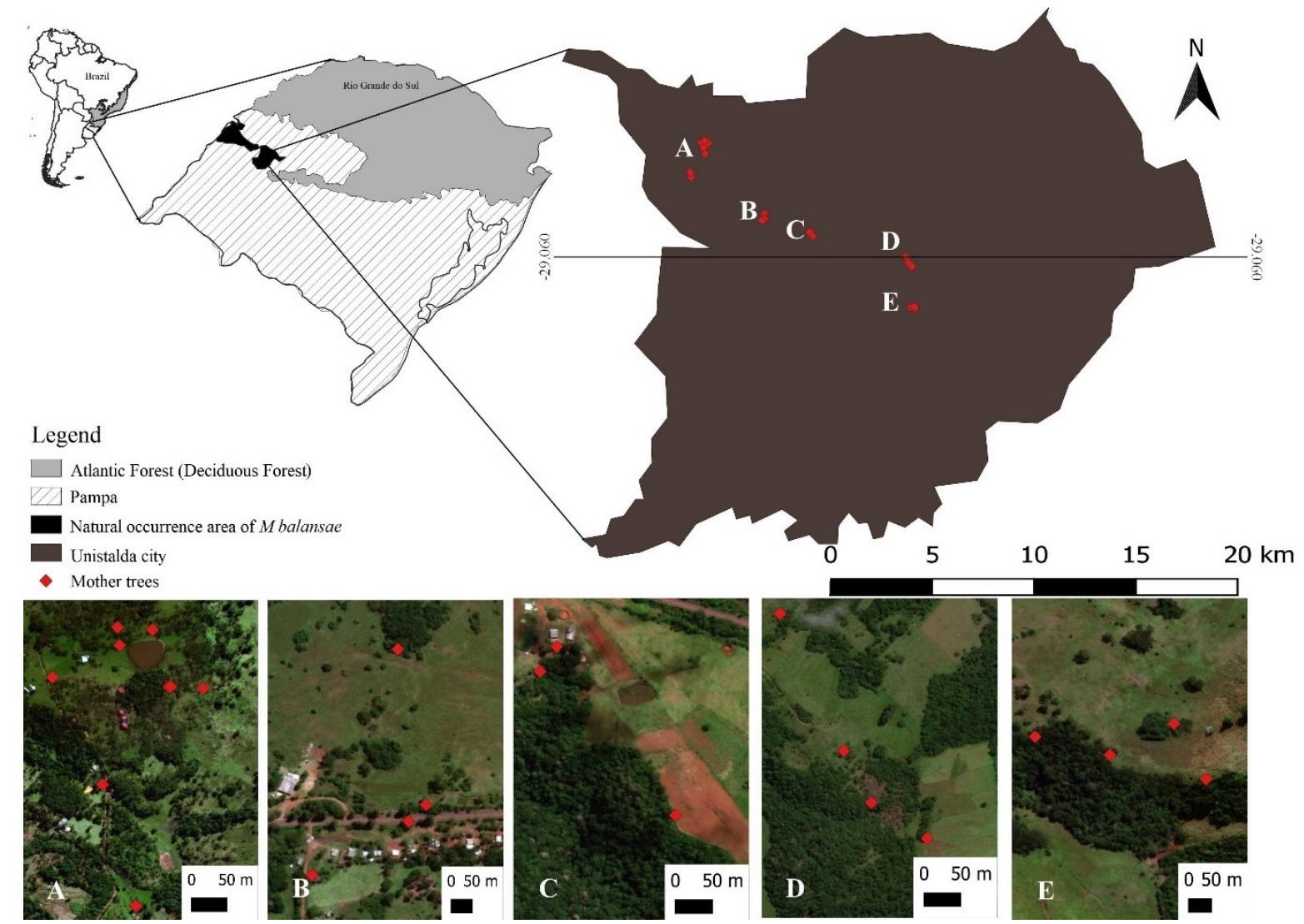

Figure 1. Location of diaspores collection and area of the natural occurrence of Myracrodruon balansae (Anacardiaceae). Red dots indicate the mother trees. 
the diaspores were dried at room temperature for two days to remove persistent petals at Laboratório de Silvicultura e Viveiro Florestal (UFSM). The diaspores were placed into paper bags, then inside a kraft paper cylinder, and stored in a dry cold chamber [temperature of $18{ }^{\circ} \mathrm{C}$ and relative humidity $(\mathrm{RH})$ of ca. $48 \%$ ] for 14 days.

\section{Substrate for germination testing}

Diaspores were characterized according to the Brazilian Rules for Seed Testing after two weeks of initial storage (Brasil, 2009a). We determined the weight of one thousand diaspores (TDW) using eight replications of 100 diaspores, with results expressed in grams. The evaluation of water content was calculated by oven drying ( $105{ }^{\circ} \mathrm{C} \pm 3$ for 24 hours), with two replications of approximately five grams of intact diaspores, with results expressed based on fresh weight (Brasil, 2009a). The germination test was carried out with four replications of 50 diaspores, evaluating the following six substrates in gerbox-type transparent plastic boxes (treatments): OS - on top of sieved fine sand; BS - between two layers of sieved fine sand; OV - on top of vermiculite; BV - between two layers of vermiculite; BP - on top of blotter paper; BBP - between blotter paper; and one out of gerbox PR- into paper rolls.

The amount of water added to the sand and vermiculite treatments followed the methodology proposed by Brasil (2009a) and Brasil (2013) of water volume for $60 \%$ of field capacity. The paper substrate was moistened with 2.5 times the weight of the paper. All substrates and distilled water were autoclaved $\left(120^{\circ} \mathrm{C}\right.$ for $\left.2 \mathrm{~h}\right)$, and the gerbox asepsis was performed with alcohol 70 GL (degrees Gay-Lussac). The surface sterilization of diaspores was done by immersion in alcohol $70 \%$ and in a commercial sodium hypochlorite solution $(2.5 \% \mathrm{Cl})$ at $1 \%(\mathrm{p} / \mathrm{p})$, both for two minutes, then rinsed in distilled water for two minutes.

Germination assays were carried out in a Mangelsdorf germination chamber $\left(25 \pm 3{ }^{\circ} \mathrm{C}\right.$ under constant light), and the evaluations were scored every seven days until the end of the test. Normal seedlings were evaluated (Brasil, 2009a), and the Germination Speed Index (GSI) was calculated (Maguire, 1962). At the end of the germination test, the percentage of dead diaspores was evaluated, according to Brasil (2013). The experiment was set in a complete randomized design.

\section{Storage of diaspore-borne fungi}

Diaspore storage was carried out in three environments right after the initial characterization: Wet Cold Chamber WCC (temperature $8{ }^{\circ} \mathrm{C}$ and relative humidity $(\mathrm{RH})$ around $86 \%)$; Refrigerator - REF ( $3{ }^{\circ} \mathrm{C}$ and $48 \%$ of $\mathrm{RH}$ ); and Room Temperature - ROOM ( $24 \pm 3{ }^{\circ} \mathrm{C}$ and variable $\mathrm{RH}$ ) placed in kraft paper bags. The evaluation of water content in diaspores, germination, and diaspore-borne fungi tests was evaluated after 6, 12, and 18 months of storage. The experiment was conducted in a completely randomized design with four replications in factorial form, environment $(A) \times$ storage time (D) $(3 \times 3)$.

The test for diaspore-borne fungi was carried out at Laboratório de Fitopatologia Elocy Minussi, Department of
Phytosanitary Protection, UFSM (29 43' 7" S, 53 43' 0" O). The diaspores were placed on top of two sterilized blotter papers and added distilled water with 2.5 times the weight of the paper, in four replications of 25 diaspores (Brasil, 2009b). Incubation was performed in a chamber $\left(25^{\circ} \mathrm{C}\right.$ under $12-$ hour photoperiod) for seven days. The fungi identification was based on morphologic characteristics, visualized in each diaspore with a microscope and specialized bibliography (Barnett \& Hunter, 1972).

\section{Data analysis}

The statistical analysis was conducted using the software $R$ (R Core Team, 2018) at package ExpDes.pt, with data submitted to variance analysis (ANOVA). We evaluated the normality assumptions of the residuals, according to the Shapiro-Wilk test, and homogeneity of variance, according to the Bartlett test. First, we analyzed the qualitative factor (substrate) through the Scott-Knott test $(p<0.05)$. In the storage experiment, we considered the effects of the environment $(A)$ $x$ time (D). When we observed the interaction between the treatments, a regression analysis $(p<0.05)$ was performed. Otherwise, the means were compared by the Scott-Knott test $(p<0.05)$.

\section{Results}

\section{Substrate for germination testing}

Immediately after collection, the diaspore lot showed a value of 170.648 diaspores $\mathrm{kg}^{-1}$ and a weight of a thousand diaspores of $5.86 \mathrm{~g}$ (CV 3.34\%). Diaspore water content was $12.2 \%$ (CV 5.06\%). For all substrates, the first germination occurred before the 7th day and was completed by the 28th day. There were no significant differences among substrates related to germination and dead diaspores (Table 1). The low germination rate indicates the low viability of diaspores. There were significant differences among substrates with the Germination Speed Index. The highest result was found in the substrates on top of sieved fine sand (OS), on top of vermiculite (OV), between two layers of vermiculite (BV), and on top of blotter paper (BP) ( $p<0.0019$; Table 1).

The diaspore-borne fungi test before storing indicates the occurrence of the fungi genera Aspergillus spp., with $19 \%$ of contamination, Penicillium spp. (14\%), and Alternaria spp. (13\%). On the other hand, Phoma spp., Phomopsis spp., Fusarium spp., and Cladosporium spp. showed only $2 \%$ of contamination.

\section{Storage of diaspores}

The initial water content of diaspores showed a value of $12.21 \%$ (Fig 2). After six months, the mean values were $18.1 \%$ (WCC), 10.9\% (ROOM), and $9.4 \%$ (REF). The mean values remained constant for 18 months after storage, $17.76 \%$, $12.35 \%$, and $10.32 \%$, respectively.

The analysis of variance showed a significant interaction between environments and storing time $(p<0.05)$ for germination, Germination Speed Index, and dead diaspores. 
Table 1. Mean values of germination (G), Germination Speed Index (GSI), dead diaspores (DD) of Myracrodruon balansae diaspores, obtained in the germination test performed in seven different types of substrates.

\begin{tabular}{cccc}
\hline Substrates & G (\%) & GSI & DD (\%) \\
\hline OS & $32.5 \mathrm{a}$ & $2.62 \mathrm{a}$ & $67.5 \mathrm{a}$ \\
BS & $26.0 \mathrm{a}$ & $1.96 \mathrm{~b}$ & $74.0 \mathrm{a}$ \\
OV & $38.0 \mathrm{a}$ & $3.05 \mathrm{a}$ & $62.0 \mathrm{a}$ \\
BV & $36.5 \mathrm{a}$ & $3.03 \mathrm{a}$ & $63.5 \mathrm{a}$ \\
BP & $31.0 \mathrm{a}$ & $2.48 \mathrm{a}$ & $69.0 \mathrm{a}$ \\
BBP & $24.5 \mathrm{a}$ & $1.40 \mathrm{~b}$ & $75.5 \mathrm{a}$ \\
PR & $23.5 \mathrm{a}$ & $1.71 \mathrm{~b}$ & $76.5 \mathrm{a}$ \\
Mean & 30.28 & 2.32 & 69.71 \\
CV (\%) & 26.88 & 24.39 & 9.38 \\
ANOVA & $2.03^{\text {ns }}$ & $5.26^{*}$ & $2.03^{\mathrm{ns}}$ \\
\hline
\end{tabular}

*Means followed by different letters differ between each other by the Scott-Knott ( $p<$ $0.05)$ ns - non-significant; CV - coefficient of variation; OS - on top of sieved fine sand; BS - between two layers of sieved fine sand; OV - on top of vermiculite; BV - between two layers of vermiculite; BP - on top of blotter paper; BBP - between blotter paper; PR-into paper rolls.

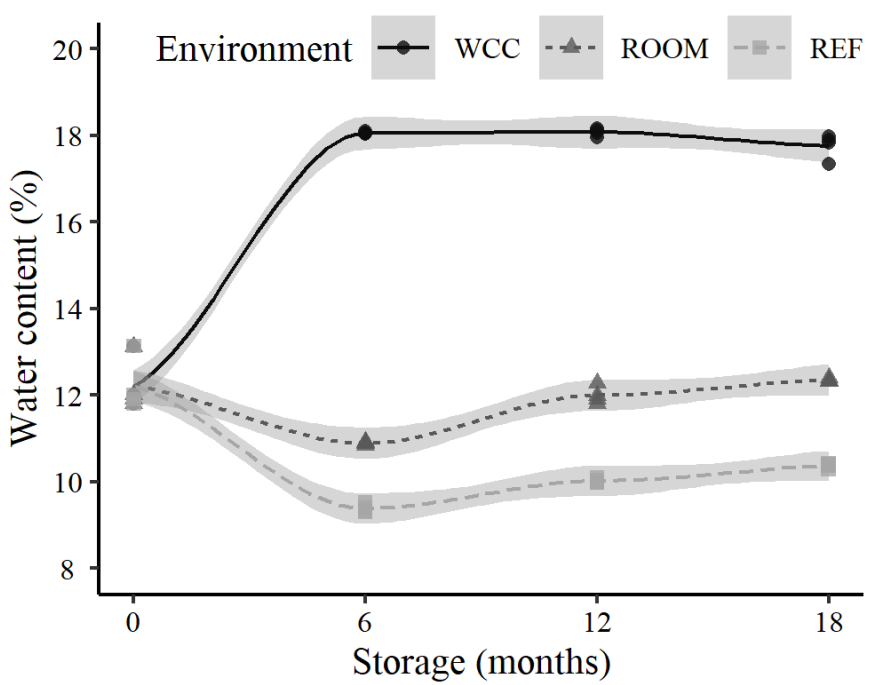

Figure 2. Diaspore water content estimated along time (lines) and confidence band ( $p<0.05$ ) (lighter areas) of Myracrodruon balansae diaspores stored for 18 months. WCC - Wet Cold Chamber; ROOM - Room Temperature; REF - Refrigerator.

The low temperature and relative humidity in REF was the best condition for storing diaspores of $M$. balansae, showing a quadratic model in this environment. The maximum germination percentage was estimated at the $8^{\text {th }}$ month (42\%), as well as the Germination Speed Index (3.8) in the refrigerator (Figures $3 \mathrm{~A}$ and $3 \mathrm{~B})$. By the end of storing ( $18^{\text {th }}$ month), the values decreased to $18 \%$ for germination, and 1.78 for GSI. In WCC at six months, we observed $23 \%$ of germination and GSI 1.9 , while in $L A B$, the germination was $8.45 \%$ and GSI 0.64 . The values of dead diaspores were inverse to those observed for the germination percentage (Figure 3C).

In the analysis of diaspore-borne fungi, 17 genera were found over the 18 months of evaluation: Alternaria spp. (4\%), Aspergillus spp. (27.5\%), Penicillium spp. (31\%), Phomopsis spp. (2.2\%), Phoma spp. (0.75\%), Fusarium spp. (2.9\%), Epicoccum spp. (0.25\%), Bipolaris spp. (0.25\%), Curvularia spp. (1.2\%), Colletotrichum spp. (1.1\%), Verticillium spp.
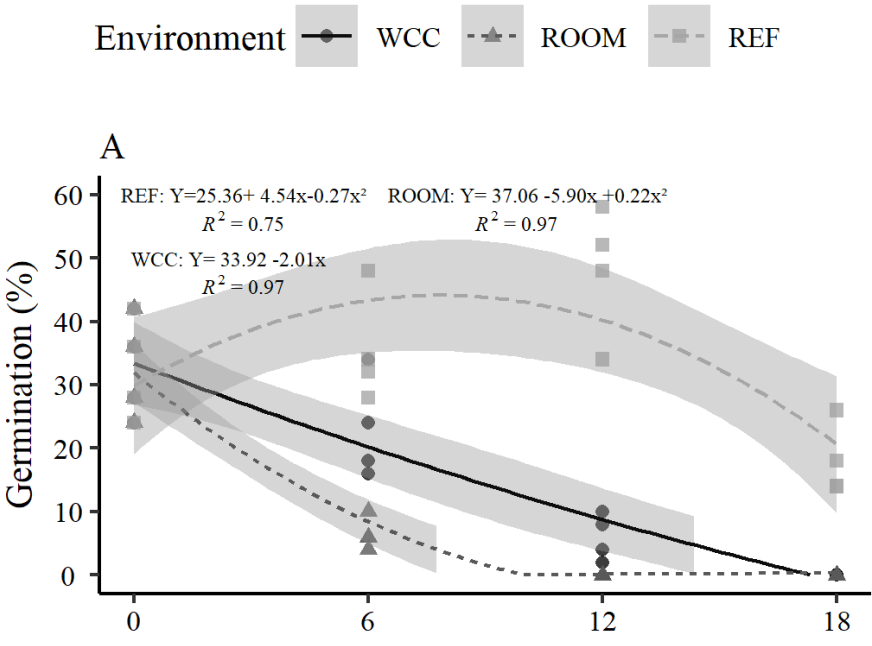

B
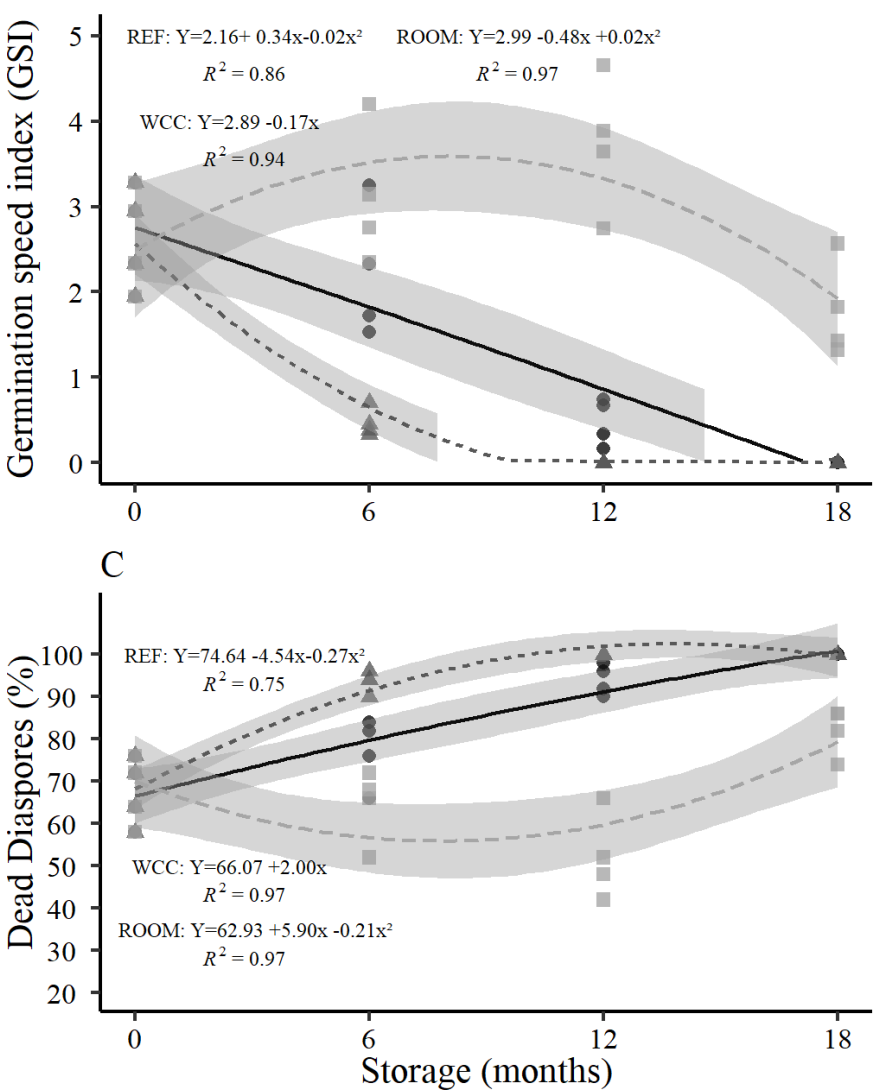

Figure 3. (A) Germination (\%), (B) Germination Speed Index, and (C) Dead Diaspores estimated along time (lines) and confidence band ( $p<0.05$ ) (lighter areas) for Myracrodruon balansae diaspores stored for 18 months in three environments: WCC - Wet Cold Chamber; ROOM - Room Temperature; REF - Refrigerator.

(0.1\%), Cladosporium spp. (0.6\%), Rhizoctonia spp. (0.1)\%, Rhizopus spp. (1.2\%), Botrytis spp. (0.4\%), Chaetomium spp. (0.1\%), and Pestalotiopsis spp. (0.2\%). Among these genera, Alternaria spp., Aspergillus spp., and Penicillium spp. occurred in all evaluations, corresponding to $62.5 \%$ of the total, with significance in the variance analysis $(p<0.05)$.

The genus Alternaria had a higher occurrence in WCC at the beginning of the tests decreasing along with the storage. 
Table 2. Incidence of the main fungi found in stored diaspores of $M$. balansae in three environments over 18 months.

\begin{tabular}{|c|c|c|c|c|c|c|c|c|c|}
\hline & \multicolumn{3}{|c|}{ Alternaria spp. (\%) } & \multicolumn{3}{|c|}{ Aspergillus spp. (\%) } & \multicolumn{3}{|c|}{ Penicillium spp. (\%) } \\
\hline & \multicolumn{9}{|c|}{ Storage (months) } \\
\hline & 6 & 12 & 18 & 6 & 12 & 18 & 6 & 12 & 18 \\
\hline WCC & $13.0 \mathrm{Bb}^{*}$ & $1.0 \mathrm{Aa}$ & $0 \mathrm{Aa}$ & $24.5 \mathrm{Ba}$ & $5.0 \mathrm{Aa}$ & $3.0 \mathrm{Aa}$ & $17.0 \mathrm{Aa}$ & $85.0 \mathrm{Bb}$ & $100.0 \mathrm{Cb}$ \\
\hline ROOM & $2.0 \mathrm{Aa}$ & $\mathrm{OAa}$ & $3.0 \mathrm{Aa}$ & $19.0 \mathrm{Aa}$ & $55.0 \mathrm{BC}$ & $41.0 \mathrm{Bb}$ & $12.0 \mathrm{Aa}$ & $12.0 \mathrm{Aa}$ & $18.0 \mathrm{Aa}$ \\
\hline REF & $5.0 \mathrm{Aa}$ & $4.0 \mathrm{Aa}$ & $8, \mathrm{Aa}$ & $20.0 \mathrm{Aa}$ & $28.0 \mathrm{Ab}$ & $33.0 \mathrm{Ab}$ & $12.0 \mathrm{Aa}$ & $11.0 \mathrm{Aa}$ & 12.0 Aa \\
\hline Mean & & 4.0 & & & 27.5 & & & 31.0 & \\
\hline
\end{tabular}

Notes: * Means followed by the same capital letter on the line (time) and small on the column (environments) are not different from each other according to the Scott-Knott ( $\mathrm{p} \geq 0.05$ ) $\mathrm{CV}$ = coefficient of variation; REF - Refrigerator; ROOM - Room Temperature; WCC - Wet Cold Chamber.

Aspergillus had similar averages with a reduced incidence in the WCC environment, but for ROOM and REF, this genus had a high occurrence. The genus Penicillium occurred in all studied environments but had a significant increase in the WCC with a $100 \%$ occurrence in the last evaluation, differing from the ROOM and REF, which had no significant difference (Table 2).

\section{Discussion}

Despite its ecological and economic importance, $M$. balansae is a rarely studied species Carvalho (2003). Our initial findings are following other studies for the genus. Virgens et al. (2012) observed values close to $10 \%$ of water content in this genus, while Diniz et al. (2015) found values between 18 to 23\% for diaspores of Myracrodruon urundeuva Fr. All. from different localities. The water content in the seeds can be naturally variable (Wielewicki et al., 2006), which is influenced by the acquisition of desiccation tolerance or not, the weather conditions during the maturation process, as well as the ripening phase of fruits (Aimi et al., 2016). The water content influences the number of seeds per $\mathrm{kg}^{-1}$ since Carvalho (2003) found values close to 150 thousand diaspores $\mathrm{kg}^{-1}$ and according to the same author, the seed water content observed in this study classifies the diaspores of Myracrodruon as orthodox.

The low percentage of germination suggests the irregularity in the ripening of fruits and seeds among trees, as well as in the mother tree itself, corroborating Carvalho (2003), who reports that $M$. balansae has variable germination according to the year of the collection (15 to 96\%), the same author describes the germination of $M$. balansae as initiating in 4 days and completing the germination process in 34 days after sowing. Further research carried out with $M$. urundeuva showed that the germination process started before seven days (Pacheco et al., 2006; Virgens et al., 2012). The lack of morphological markers that define the appropriate moment for the collection was expected.

In this sense, Wielewicki et al. (2006) suggest that individual, recurrent variations of environmental and genetic factors may occur in the same species, causing physical and physiological differences in seeds. Araujo et al. (2018) highlighted the importance of planning the collection period, due to the variation in fruit ripening among trees, as well as the fruiting period among subsequent years. The adequate period for seed (fruit/diaspore) collection is during the point of maximum physiological quality, which coincides with high germination, greater accumulation of dry matter, marked water loss, and maximum vigor. These facts could be associated with the fruit disconnection of the mother tree (Lorza et al., 2015). Thus, when the species is rarely studied, there is a risk of collecting immature diaspores, which, consequently, will result in reduced germination and vigor, a fact that should be emphasized with $M$. balansae.

The substrates did not influence $M$. balansae diaspores germination, corroborating Pacheco et al. (2006) that evaluated substrates, between blotter paper, on top of blotter paper, between sand, on top of sieved fine sand, between vermiculite, on top of vermiculite, between coconut powder, and on top of coconut powder for $M$. urundeuva germination at $25^{\circ} \mathrm{C}$. Our results showed a high GSI with these substrates: on top of vermiculite (OV), between two layers of vermiculite (BV), on top of sieved fine sand (OS), and on top of blotter paper (BP), which OS and BV were evidenced as adequate by Gasparin et al. (2012) in a study with seeds of Allophylus edulis (A.St.-Hil. et al.,) Radlk. Brasil (2009a; 2013) recommends the use of substrates between two layers of sand, between two layers of vermiculite, and the paper blotter on top of sieved fine sand for woody species. Thus, given the options described in Brasil (2009a; 2013) and based on our results, we suggest the use of paper blotter on top of sieved fine sand to M. balansae germination test. It's adequate for this procedure, easy to handle and evaluate, and also of low cost. However, our results also support the use of substrates on top of vermiculite, between two layers of vermiculite, and on top of blotter paper.

During storing, the germination results observed for REF were positive due to prolongated diaspores viability. These results also suggest REF as a good alternative that can facilitate storage in rural properties and small nurseries. On the other hand, the values observed for the diaspores in the WCC and ROOM showed that these environments could not preserve diaspores viability until 18 months. The conservation of orthodox seeds for long periods requires low temperature and low relative environmental humidity in order to increase longevity during storage (Gasparin et al., 2018). In our case, the refrigerator had the best conditions (low temperature and $\mathrm{RH}$ ) when compared with other environments, even when a permeable package was used. 
The rapid loss of viability in the laboratory environment was also found in other seeds of woody species (Gasparin et al., 2013). This fact is generally observed in orthodox seeds, where high temperatures and relative air humidity increase the metabolic and respiratory activities of seeds, accelerating the rate of deterioration (Azevedo et al., 2003). Moreover, the reduction in seed water content decreases metabolic activity and prolongs viability, decreasing fungal infestation. In this sense, Guedes et al. (2012) pointed out that M. urundeuva diaspores packed in a kraft paper bag should be stored in a refrigerator to maintain their quality for up to 240 days. Thus, $M$. balansae could present diaspores tolerant to desiccation, so the reduction in the water content of the diaspores soon after collection, may reduce the rate of deterioration and, consequently, increase their longevity. Another important aspect is related to the packaging, which must be impermeable such as glass, which prevents water absorption by external environment conditions in seeds.

The fungi with the highest initial occurrence remained throughout the sanitary analyses, but in a refrigerator environment, Alternaria and Penicillium had a reduced or non-significant occurrence (Table 2). The other genera of fungi observed in this study also occur in seeds of other native forest species in Southern Brazil, such as Cabralea canjerana (Vell.) Mart. (Aimi et al., 2016), Bauhinia forficata Link, Cedrela fissilis Vell., Parapiptadenia rigida (Benth.) Brenan, Senegalia bonariensis (Gillies ex Hook. \& Arn.) Seigler \& Ebinger. (Pinheiro et al., 2016). Aspergillus and Penicillium, which had a high occurrence in WCC and ROOM, are considered rotting seed fungi and have their presence associated with inadequate storage conditions, characterized by higher seed water content, high relative humidity, and high air temperature (Santos \& Parisi 2011). In this sense, seeds from natural environments are prone to contamination by pathogens (Sales et al., 2018), and it is necessary to know the sanitary quality of the seeds to help control the pathogens for storage and seedling production (Aimi et al., 2016).

This study confirms that substrates and storage influence the quality of $M$. balansae diaspores. We identified the best substrates for germination and ideal storage conditions. Despite the high availability of diaspores, the physiological quality is limiting to germination, so identifying the appropriate time for the collection of diaspores is necessary, as well as the factors that influence seed formation and production.

\section{Conclusions}

The diaspores germination test for Myracrodruon balansae (Engl.) D.A.Santin can be performed on top of sieved fine sand, on top of vermiculite, between two layers of vermiculite, and on top of blotter paper, with initial seedling count on day seven and final seedling count on day 28 after sowing.

The storage of the $M$. balansae diaspores is possible with a $12.2 \%$ of initial water content in a low-temperature environment and $\mathrm{RH}$ (refrigerator) for 18 months. Diaspores stored in the refrigerator have more sanitary quality with a low fungal infestation. Careful attention should be given to the asepsis or fungal treatment of the stored material due to the presence of Aspergillus spp. and Penicillium spp., which are harmful to the germination and vigor of diaspores.

\section{Acknowledgments}

The authors would like to thank Coordenação de Aperfeiçoamento de Pessoal de Nível Superior (CAPES) for granting a scholarship to the first author, and Conselho Nacional de Desenvolvimento Científico e Tecnológico (CNPq) for the productivity research scholarship granted to the second author.

\section{Compliance with Ethical Standards}

Author contributions: Conceptualization: FMB, MMA, SCA, VSF; Data curation: FMB, SCA, VSF, AMG; Formal analysis: FMB, FT; Investigation: FMB, FT, VSF; Methodology: FMB, SCA; Project administration: $M M A$; Writing - original draft: $F M B$, SCA; Writing - review \& editing: MFBM, AMG, FT,EG

Conflict of interest: There is no conflict of interest

Financing sources: Coordenação de Aperfeiçoamento de Pessoal de Nível Superior (CAPES) - Financing Code 001, and Conselho Nacional de Desenvolvimento Científico e Tecnológico (CNPq)

\section{Literature Cited}

Aimi, S.C.; Araujo, M.M.; Muniz, M.F.B.; Walker, C. Teste de sanidade e germinação em sementes de Cabralea canjerana (Vell.) Mart. Ciência Florestal, v.26, n.4, p.1361-1370, 2016. https://doi. org/10.5902/1980509825155.

Araujo, M.M.; Wielewicki, A.P.; Zavistanovicz, T.C.; Aimi, S.C.; Felippi, M.; Adenesky Filho, E.; Oliveira, L. M. Fenologia de espécies arbóreas voltada à coleta de sementes no sul do Brasil. In: Araujo, M.M.; Navroski, M.C.; Schorn, L.A. (Orgs.); Produção de sementes e mudas um enfoque à silvicultura. 1.ed. Santa Maria, Editora UFSM, 2018. p. 41-58.

Azevedo, M.R.Q.A.; Gouveia, J.P.G.; Trovão, D.M.M.; Queiroga, V. P. Influência das embalagens e condições de armazenamento no vigor de sementes de gergelim. Revista Brasileira de Engenharia Agrícola e Ambiental, v.7, n.3, p.519-524, 2003. https://doi. org/10.1590/S1415-43662003000300019.

Barnett, H.; Hunter, B. Illustrated genera of imperfect fungi. 4.ed. St. Paul: Amer Phytopathological Society, 1999. 240p.

Brasil. Ministério da Agricultura, Pecuária e Abastecimento. Instruções para análise de espécies florestais. Brasília: MAPA; ACS, 2013. 98p.

Brasil. Ministério da Agricultura, Pecuária e Abastecimento. Manual de análise sanitária de sementes. Brasília: MAPA; ACS, 2009b. 202p.

Brasil. Ministério da Agricultura, Pecuária e Abastecimento. Regras para Análise de Sementes. Brasília: MAPA; ACS, 2009a. 395p.

Carvalho, P.E.R. Espécies arbóreas brasileiras. 1.ed. Brasília: Embrapa Informação Tecnológica; Embrapa Florestas, 2003. 1035p. 
Contreras-Toledo, A.R.; Cortés-Cruz, M.; Costich, D.E.; Rico-Arce, M.L.; Brehm, J.M.; Maxted, N. Diversity and conservation priorities of crop wild relatives in Mexico. Plant Genetic Resources: Characterization and Utilization, v.17, n.2, p.140-150, 2019. https://doi.org/10.1017/S1479262118000540.

Diniz, Q.R.; Diniz, B.L.M.T.; Azeredo, G.A.; Souza, V.C.; Pereira, E.M. Potencial germinativo de sementes de aroeira Myracrodruon urundeuva Fr. coletadas de população no cariri paraibano. Revista Verde, v. 10, n. 1, p. 154-159, 2015. https://doi.org/10.18378/ rvads.v10i1.3442.

Gasparin, E.; Araujo, M.M.; Avila, A.L.; Wielewicki, A.P. Identificação de substrato adequado para germinação de sementes de Allophylus edulis (A. St.-Hil., A. Juss. \& Cambess.) Radlk. Ciência Florestal, v.22, n.3, p.625-630, 2012. https://doi. org/10.5902/198050986628.

Gasparin, E.; Araujo, M.M.; Franco, E.T.H.; Oliveira, L.M. Armazenamento de sementes de espécies florestais. In: Araujo, M.M.; Navroski, M.C.; Schorn, L.A. (Orgs.); Produção de sementes e mudas um enfoque à silvicultura. 1.ed. Santa Maria: Editora UFSM, 2018. p.99-120.

Gasparin, E.; Araujo, M.M.; Tolfo, C.V.; Foltz, D.R.B.; Magistrali, P.R. Substrates for germination and physiological quality of storage seeds of Parapiptadenia rigida (Benth.) Brenan. Journal of Seed Science, v.35, n.1, p.77-85, 2013. https://doi.org/10.1590/S231715372013000100011.

Guedes, R.S.; Alves, E.U.; Bruno, R.L.A.; Gonçalves, E.P.; Costa, E.G.; Medeiros, M.S. Armazenamento de sementes de Myracrodruon urundeuva Fr. All. em diferentes embalagens e ambientes. Revista Brasileira de Plantas Medicinais, v.14, n.1, p.68-75, 2012. https:// doi.org/10.1590/S1516-05722012000100010.

Hoffmann, P.M.; Blum, C.T.; Velazco, S.J.E.; Gill, D.J.C.; Borgo, M. Identifying target species and seed sources for the restoration of threatened trees in southern Brazil. Oryx, v.49, n.3, p.425-430, 2015. https://doi.org/10.1017/S0030605314001069.

Lorza, R. F.; Castro, A. G.; Figliolia, M. B. Planejamento e técnicas de coleta de sementes. In: Piña-Rodrigues, F.C.M.; Figliolia, M. B.; Silva, A. (Orgs.). Sementes florestais tropicais: da ecologia a produção. Londrina: Abrates, 2015. p.190-205.
Luz, C. L. da S.; Pirani, J. R.; Valente, A. S. M.; Fernandez, E. P.; Penedo, T. S. A.; Borges, R. A. X. Anacardiaceae. In: Martinelli, G.; Moraes, M. A. (Orgs.). Livro vermelho da flora do Brasil. 1.ed. Rio de Janeiro: Andrea Jakobsson; Instituto de Pesquisas Jardim Botânico do Rio de Janeiro, 2013. p.140-143. http://cncflora.jbrj. gov.br/arquivos/arquivos/pdfs/LivroVermelho.pdf. 06 Jun. 2020.

Maguire, J.D. Speed of germination-aid in selection and evaluation for seedlings emergence and vigor. Crop Science, v.1, p.176-177, 1962. https://doi.org/10.2135/cropsci1962.0011183X000200020033x.

Pacheco, M.V.; Matos, V.P.; Ferreira, R.L.C.; Feliciano, A.L.P.; Pinto, K.M.S. Efeito de temperaturas e substratos na germinação de sementes de Myracrodruon urundeuva Fr. All. (Anacardiaceae). Revista Árvore, v. 30, n. 3, p. 359-367, 2006. https://doi. org/10.1590/S0100-67622006000300006.

Pinheiro, C.G.; Lazarotto, M.; Brião Muniz, M.F.; Redin, C.G.; Dos Santos, M.V. Efeito da assepsia superficial na germinação e incidência de fungos em sementes de espécies florestais. Pesquisa Florestal Brasileira, v.36, n.87, p.253-260, 2016. https:// doi.org/10.4336/2016.pfb.36.87.1234.

R Core Team. R: A language and environment for statistical computing. Vienna: R Core Team, 2018.

Sales, N.I.S.; Leão, E.U.; Giongo, M.; Santos, G.R. Patogenicidade e transmissão de fungos associados às sementes de Tectona grandis L.f. Ciência Florestal, v.28, n.3, p.970-978, 2018. https:// doi.org/10.5902/1980509833369.

Santos, A.F.; Parisi, J.J.D. Características dos fungos associados às sementes florestais. In: Santos, A.F.; Parisi, J.J.D.; Mentem, J. O. M. (Orgs.); Patologia de sementes florestais. Colombo: Embrapa Florestas, 2011. p.69-86.

Virgens, I.O.; Castro, R.D.; Fernandez, L.G.; Pelacani, C.R. Comportamento fisiológico de sementes de Myracrodruon urundeuva Fr. All. (Anacardiaceae) submetidas a fatores abióticos. Ciência Florestal, v.22, n.4, p.681-692, 2012. https:// doi.org/10.5902/198050987550.

Wielewicki, A.P.; Leonhardt, C.; Schlindwein, G.; Medeiros, A.C.S. Proposta de padrões de germinação e teor de água para sementes de algumas espécies florestais presentes na região Sul do Brasil. Revista Brasileira de Sementes, v.28, n.3, p.191-197, 2006. https://doi.org/10.1590/S0101-31222006000300027. 